\title{
SEJARAH INDUSTRI KERAJINAN KAIN TENUN SONGKET CUAL (IKAT) DI DUSUN SEMBERANG KABUPATEN SAMBAS
}

\author{
Febrianti, Andang Firmasyah, Astrini Eka Putri \\ Program Studi Pendidikan Sejarah FKIP Untan Pontianak \\ Email: febriantistar8899@gmail.com
}

\begin{abstract}
This research is entitled "The History of the Cual Ikat Songket Woven Craft Industry in Seberang Hamlet, Sambas Regency. The formulation of the problem in this study are: (1) How to make Songket Ikat Woven Fabrics in Sember Hamlet, Sambas Regency, (2) How is the production process of Songket Ikat Woven Fabrics in Seberang Hamlet, Sambas Regency, (3) How is the marketing process of the Woven Fabric Craft industry Songket Ikat in Dusun Sember, Sambas Regency from the past until now, (4) How to use Songket Ikat Woven Fabrics in Seberang Hamlet, Sambas Regency, (5) The motifs produced from Songket Ikat Woven Fabrics in Dusun Seberang, Sambas Regency. The method used in this research is the historical research method. The steps used in this historical research method consist of topic selection, heustrics, verification, interpretation, and historigraphy. With the aim of developing the craft of Songket Ikat Woven Fabrics to be better known by young people. In terms of economic and social development, the craft of Songket Ikat Woven Fabrics is quite developed, although from an economic point of view, the people of Dusun Semberang do not guarantee their lives, most of the weavers choose to become Indonesian Workers (TKI) in Malaysia and Brunei Darussalam, because being a TKI is promising economically. their economy. Meanwhile, from a social perspective, not all women can weave or want to weave, on average, weavers are housewives, whereas young people are rarely found who want to weave, according to them it is a boring thing, but for young people who want to weave. hobby and willing to learn.
\end{abstract}

Keywords: Weaver, Economy, Social, Society

\section{PENDAHULUAN}

U. Riza Fahmi (2018) menyatakan bahwa Kabupaten Sambas juga memiliki kain tenun Songket yang dikenal dengan nama kain Lunggi Sambas. Merupakan salah satu hasil kreativitas masyarakat di Kabupaten Sambas. Bentuk akhir dari pencurian ide yang dipahami dan diapresiasi kemudian diaplikasikan dalam bentuk secarik kain. Kerajinan tenun Songket Sambas sendiri sudah ada sejak lama.

Kabupaten Sambas memiliki tradisi budaya yang sangat terkenal. Tradisi budaya ini merupakan tradisi budaya menenun Songket Sambas. Sejak saat itu, tradisi menenun menjadi seni kriya dan diwariskan secara turun-temurun hingga saat ini. Orang Sambas menyebutnya Kain Lunggi atau juga disebut kain bannang ammas (kain benang emas). Disebut kain benang emas 
dikarenakan salah satu bahan yang digunakan adalah benang emas yang berwarna kuning keemasan. (Marjanto Kun Damardjati dan Asnaini, 2011:1).

Sejak dahulu kala, salah satu tradisi yang terbungkus dalam sebuah penemuan dan masih bertahan hingga saat ini adalah Tenun Songket. Berbicara tentang kain songket, beberapa daerah masyarakat memilikinya seperti Palembang, Riau, dan Minangkabau meskipun ada perbedaan. Biasanya terletak pada jenis dan susunan motifnya, namun pada dasarnya kain tenun songket sendiri lahir dari tradisi melayu. Tenun songket di Kabupaten Sambas merupakan kebanggaan masyarakat Sambas.

Kain tenun songket samba pada zaman dahulu biasanya dikenakan pada acara pernikahan, musyawarah, menghadiri undangan pejabat atau raja daerah, khitanan, atau sejenisnya. Saat ini untuk Kain Tenun Songket Ikat sendiri sudah tidak sering digunakan untuk majelis-majelis besar, sekarang hanya sebagai pajangan atau hanya untuk diwariskan saja.

Kain tenun Songket ini sangat cocok untuk wanita untuk menghadiri pertemuanpertemuan tertentu, misalnya menghadiri undangan penguasa provinsi atau undangan raja. Begitulah kain tenun Songket Sambas memiliki nilai budaya yang tinggi dalam masyarakat lokal, dan menjadi kebanggan bagi orang yang memakainya.

Pada proses awal pembuatan kerajinan kain Tenun Songket itu sendiri sebagai bahan utama yang digunakanyaitu benang Sutra, setelah itu benang dipindahkan atau di giring yaitu menarik benang sebanyak 5 lembar. Kain tenun Songket Sambas termasuk dalam katagori benda hasil ekonomi, kreatif, khususnya produk kerajinan. Alat-alat yang mengandung mesin bisa digunakan selama kontribusi secara manual dan langsung dari pengrajin tetap sebagai komponen yang terbesar dari produk jadi. Kerajinan dibuat dari bahan-bahan mentah dan dapat produksi dalam jumlah yang tak terbatas. Sebagian produk-produk bermanfaat, estetik, artistik, kreatif, ekspresif secara budaya, dekoratif berfungsi, tradisional, religius dan mengandung simbol-simbol sosial dan punya arti.

Kain Tenun Songket Sambas merupakan benda budaya yang keberadaannya diwariskan dari generasi sebelumnya kepada generasi berikutnya. Dengan demikian, kain tenun Songket Sambas merupakan salah satu warisan budaya (cultural heritage) masyarakat Sambas. Cultural heritage memilki dua padanan arti dalam Bahasa Indonesia, yaitu pustaka budaya dan warisan budaya.

Menurut Laretna Adhisakti Cultural Heritage mengandung pengertian sebagai pustaka budaya. Kata pusaka budaya tersebut seringkali dipakai dalam komunitas pecinta dan pelestarian benda-benda budaya, sehingga lebih populer di kalangan praktisi pelestari benda budaya. Tidak bisa terhitung lagi sebagian besar masyarakatnya pencairan ekonominya itu berasal dari penghasil tenun, tak kala lelaki juga ada sebagian ada yang menenun. Dari zaman dulu sampai sekarang kondisinya masyarakat jumlah pengrajin Industri kerajinan kain Tenun Songket di Sambas sudah lama ada sejak sekitar 300 tahun yang lalu bersamaan dengan adanya tradisi Keraton yang ada di Kabupaten Sambas. Jaman keemasan Tenun Songket Sambas bertahan sampai tahun 1970-an, namun setelah tahun-tahun tersebut keadaan mulai tidak berpihak kepada industri kerajinan kain Tenun Songket Sambas tersebut.

Menurut wawancara pada bulan januari dan maret yang dilakukan oleh peneliti. Pada saat tahun 1990-2000 penjualan Tenun Songket Sambas turun drastis, penghasilanya tidak stabil karena ada krisis moneter dan pada saat itu pengrajin kain tenun vakum sementara (tidak ada kegiatan), dan pada tahun 20002010 pengrajin kain tenun memulai kembali aktivitas menenun dan pemasarannya pun lancar sampai sekarang.Sebelumnya tahun 1998-2000 Sambas masih menjadi kecamatan belum pindah ke Kabupaten. Sehingga banyak diantara mereka lebih memilih pekerjaan lain di luar sektor kerajinan, bahkan, banyak perajin yang beralih 
pekerjaan menjadi Tenaga Kerja Indonesia (TKI) ke Malaysia dan Brunei. Bahwa 30 persen perajin kain Tenun Songket saat itu justru memilih menjadi TKI di Malaysia, bahkan banyak pula perajin dari daerah Sambas yang menjadi penenun di Brunei karena lebih menjanjikan dari segi pendapatan. Keadaan ini sangat mengingatkan dari tahun ke tahun jumlah penenun mengalami penurunan. Tawaran bayaranyang lebih tinggi daripada upah di Indonesia apalagi di Kabupaten Sambas, menjadi salah satu faktor kuat yang mendorong para perajin hijrah ke Brunei dan Malaysia.

\section{KAJIAN PUSTAKA}

Masyarakat adat didefinisikan sebagai sekelompok orang yang memiliki asal-usul leluhur secara turun temurun di wilayah geografis tertentu, dan memiliki nilai ideologis, ekonomi, budaya, sosial, dan seni mereka sendiri. Tujuan utamanya ialah keinginan untuk memelihaa budaya salah satunya kain tenun ikat songket di Kabupaten Sambas untuk melestarikan dari nenek moyang secara turun menurun. Peneliti mengambil buku pertama karya Damardjati Kun Marjanto Asnaini yang berjudul "Industri kerajinan kain Tenun Sambas strategi pengembagan warisan budaya" yang terbit tahun 2011, dan di terbitkann pertama kali dalam bahasa Indonesia yang penerbit Kepel Press, Anggota IKAPI, Yogyakarta. Buku ini menjelaskan tentang sekarah kain Tenun Sambas, gambaran umum Kabupaten Sambas dan permasalahan yang ada di industri kerajinan Kain Tenun Songket di Kabupaten Sambas. Dalam buku ini menjelaskan juga tentang alat-alat yang digunakan dalam penenun serta menjelaskan kegunaan alat tersebut.

Buku kedua karya Alfian yang berjudul "Kerajinan Tenun Songket Sambas" yang terbit tahun 2009 yang menjelaskan tentang perkembagan zaman cara pembuatan kain tenun adat Sambas yang masih dikerjakan secara tradisional dengan menggunakan peralatan yang cukup sederhana, yang terbuat dari bahan yang banyak terdapat disekitar tempat tinggal.
Buku ketiga penulis Fahmi U. Riza terbentuk dari "Boklet Dinas Pendidikan dan Kebudayaan " yang terbit tahun 2018, menjelaskan kain Tenun salah satu tradisi leluhur yang dibalut sebagai penemuan dan masih bertahan hingga zaman modern adalah kain songket. Merupakan salah satu kreativitas masyarakat Kabupaten Sambas, dimana sebuah ide yang dipahami dan dihayati kemudian di aplikasikan dalam bentuk secarik kain. Berbagai motif yang terdapat di kain Tenun Songket Sambas yaitu salah satu motif Tenun Lunggi Sambas.

Buku keempat karya Muntansyir Rizal yang berjudul "Kearifan Lokal Masyarakat Melayu Sambas dalam Tinjauan Filosofis" yang terbit tahun 2016 yang menjelaskan tentang masyarakat melayu Sambas, salah satu sub suku Melayu yang memiliki keunikan tersendiri dalam hal bahasa, adat istiadat, kesenian dan lain sebagainya.

\section{METODE PENELITIAN}

Metode penelitian ini menggunakan metode penelitian sejarah yang memiliki 5 tahapan, yaitu:

1) Pemilihan topik merupakan langkah awal dalam melakukan studi sejarah. Tujuannya agar pencarian sumber sejarah dapat terarah dan tepat sasaran dengan masalah yang diteliti. Pada hakekatnya, pemilihan topik dalam diri peneliti tidak terlepas dari keintiman emosional dan keintiman intelektual. Peneliti mengambil topik tentang Sejarah kerajinan kain Tenun Songket di Dusun Semberang Kabupaten Sambas dikarenakan peneliti sangat tertarik melakukan penelitian tersebut dan peneliti juga ingin masih penelti menemukan orang yang menelitinya.

2) Pengumpulan sumber daya (Heuristik) adalah kegiatan mencari sumber untuk memperoleh data, atau bahan sejarah. Heuristik berasal dari bahasa Yunani yaitu heuristics yaitu mengumpulkan atau mencari sumber, yang artinya sumber atau sumber sejarah 
(historical sources) adalah sejumlah bahan sejarah yang tersebar dan beragam (Suhartono W. Pranoto, 2014: 29). Sumber primer adalah keterangan saksi dengan mata sendiri atau saksi dengan panca indera lain atau dengan alat mekanis seperti dictaphone, yaitu orang atau alat yang hadir pada peristiwa sejarah yang diceritakannya (secara singkat disebut mata.- Kesaksian saksi), sedangkan sumber sekunder adalah kesaksian dari siapa saja yang menjadi saksi mata, yaitu seseorang yang tidak hadir pada peristiwayang diceritakannya.

3) Verifikasi (kritik sejarah, keabsahan sumber) kegiatan menganalisis keabsahan sumber-sumber yang telah ditemukan. Ada dua hal yang dapat dilakukan yaitu melalui kritik eksternal dan kritik internal. Kritik internal merupakan penilaian terhadap keakuratan atau keaslian bahan sumber sejarah (Listiyani, 2009: 55). Tahap selanjutnya adalah kritik sumber untuk menentukan keaslian dan kredibilitas sumber sejarah. Semua sumber daya yang telah dikumpulkan diverifikasi sebelum digunakan.

4) Interpretasi sering disebut sebagai subjektivitas. Karena tanpa interpretasi sejarawan, data tidak dapat bicara. Dalam penulisan sejarah, digunakan secara bersamaan Ada tiga bentuk dasar teknik menulis yaitu deskripsi, bercerita, dan analisis. Penulisan sejarawan sebenarnya adalah keinginannya untuk menjelaskan (explain) sejarah, ada dua dorongan utama yang mendorongnya, yaitu mencipta dan menafsirkan. Dorongan pertama menuntut deskripsi dan narasi, sedangkan dorongan kedua membutuhkan analisis (Helius Sjamsudin, 2007:123).

5) Penulisan penulisan sejarah
(Kuntowijoyo, 2013) adalah suatu metode atau yang digunakan sebagai pedoman dalam penulisan peristiwa sejarah, serta menjadi tinjauan penulis dalam mengupas persoalan yang mengiringi setiap peristiwa sejarah tersebut. Penulisan sejarah atau disebut historiografi harus memperhatikan aspek kronologis (Sugeng Priyadi, 2012: 79). Historiografi adalah cara penyajian, penulisan, atau pelaporan hasil penelitian yang telah dilakukan. Penulisan sejarah harus memberikan gambaran yang jelas tentang penyelidikan. Dengan demikian Metode penelitian sejarah dipandang sebagai atau sarana bagi peneliti untuk melakukan penelitian dan penulisan sejarah melalui prosedur ilmiah dan memerlukan data yang ilmiah.

\section{HASIL DAN PEMBAHASAN}

Hasil

\section{Sejarah Kerajinan Kain Tenun Songket Ikat Sambas \\ Kain Tenun Songket Ikat Sambas}

Pada saat itu Raden Sambas mendapat ilmu berupa keahlian berupa menenun dengan diberi seperangkat alat mesin tenun oleh kesultanan Brunei yang menginginkn masyarakat sambas untuk belajar menenun. Sejak itulah proses menenun diajarkan masyarakat yang berada di sekitar istana hingga saat ini tenunan Sambas oleh masyarakat Sambas yang bermukim disekitar istana hingga menyebar dipesisir sungai Sambas kecil dari kampung tumok, dusun semberang desa sumber harapan, kampung jirak dan kampung tengguli.

Menurut Bu Nazifah (wan dare), hasil wawancara pada tanggal 18 Januari 2021 menyatakan bahwa, Menurut sejarah jaman kerajaan sudah ada tenun dari asal mulanya orang dulu lebih kreatif karena kerajinannya menata lebih bagus daripada orang sekarang. Dari Plora dan Pauna pun dimaanfaatkan orang jaman duluuntuk membuat dasar Kain Tenun Songket Ikat. Emang dasarnya untuk 
menciptakannya orang jaman dulu.Pada jaman dulu Sultan Sulaiman paling gemar dengan kerajinan yaitu salah satunya kerajinan kain tenun songket ikat, sampai saat itu satu-satunya yang dikalahkannya adalah orang Belanda. Orang Belanda sendiri menatapi kain tenun songket ikat yang terbuat dari alat-alat manual tidak bisa terpikir, karena orang Belanda sendiri alat nya sudah seperti canggih memakai mesin. Demikian juga dengan proses pembuatannya masih menggunakan cara lama sehingga memerlukan waktu yang relatif lama karena dalam satu bulan biasanya mereka mengasilkan 2-3 lembar kain saja. Seandainya dalam mengerjekan pekerjaan menenun ini agak disiplin dengan penggunaan waktu, maka dalam prosesnya dapat menghasilkan Kain Tenun dalam waktu yang relatif singkat asalkan dikerjakan dengan sungguh-sungguh dan jam kerja yang terjadwal. Hingga saat ini belum ada pembagian jam kerja yang baik bagi para perajin. Meskipun pekerjaan menenun ini merupakan pekerjaan sambilan, para perajin ini memiliki target yang hendak dicapai dan bekerja profesional. Apabila mendapatkan upah yang banyak, tentunya saja mereka harus giat dalam bekerja dan hasil yang diperoleh pun banyak pula.

\section{Pengertian Tenun}

Industri kerajinan Tenun Sambas merupakan salah satu usaha kerajinan yang hidup dan berkembang di dalam masyarakat Melayu Sambas. Usaha kerajinan ini pada awalnya dilakukan guna untuk memenuhi kebutuhan sendiri. Namun seiring perkembangan dalam dunia usaha dan kebutuhan masyarakat yang semakin meningkat, maka usaha kerajinan Tenun Sambas ini meningkat pula seperti sekarang.

Menurut Kartiwa (1993), bahwa yang dimaksud dengan teknik Tenun Ikat adalah mengikat bagian benang agar tidak diwarnai, sedangkan bagian yang tidak terikat berubah warna sesuai dengan warna yang dicelup.

Sedangkan Therik (1982) menyatakan bahwa "dinamakan Tenun Ikat karena dekorasi dasar pada Kain Tenun dilakukan dengan mengikat gambar denah dalam beberapa warna setelah ditenun".

\section{Motif-motif Tenun Songket Ikat}

Motif dalam Tenun Songket Ikat ini terdapat beberapa kelompok seperti kelompok tumbuh-tumbuhan (flora), kelompok hewan (fauna), kelompok lingkungan alam, kelompok ilmu ukur, huruf dan sebagainya. Kelompok motif yang diangkat berdasarkan tumbuh-tumbuhan (flora), seperti bunga matahari, bunga tanjung, bunga melati, bunga sebangar, bunga tapak dara, bunga penyu, bunga malek, bugga anggur, bunga jeruk, aluk paku, sapar peranggi, dan daun periya. Sedangkan kelompok motif hewan (fauna) terdiri dari ular sawak, ulat kaki seribu, ulat jangka, dan mata ayam.

Untuk kelompok motif ilmu ukur terdiri dari pismin, belah ketupat, pilin, renda, dan kota mesir, sedangkan motif yang dibuat dengan adanya pengauh lingkungan alam seperti motif bintang, awan, dan padang tibakar, motif yang berkaitan dengan huruf yang rantai "S" serta motif lain yang ada dalam Tenun Songket Ikat ini adalah kuarik, pita, parang telur, jambangan, dan gelang.

Motif-motif tersebut dikaterogikan dalam 2 kelompok yaitu kelompok primer dan kelompok sekunder. Kelompok motif utama ini ditempatkan pada badan kain atau bagian dagin yang merupakan motif utama sedangkan motif sekunder adalah motif yang terdapat pada bagian papan dan punce yang merupakan motif pendamping dari motif primer dan sekaligus sebagai pengisi bidang kain agar kelihatan lebih menarik pada kain Tenun Songket Ikat tersebut.

Menurut bu Nazifah (wan dare) hasil wawancara tanggal 18 Januari 2021 menyatakan bahwa, Sebelumnya sudah dikenal di dusun semberang, motif-motifnya semakin bertambah, karena pengrajin kain tenun sekarang ini sudah pandai memberi motif tambahan pada kain supaya tambah indah, tetapi jaman dahulubelum terlalu banyak nama kain tenun ikat, karena sekarang sudah ditambah variasi-variasi motif baru supaya lebih indah, dan sampai sekarang kain tenun ikat sendiri lebih tambah 
maju, komsumen pun banyak pertambah dan mempercayai.

Menurut informan yang telah peneliti wawancarai Kain Tenun Ikat motif zigzag ini merupakan motif terbaru. Adapun proses pembuatan Kain Tenun Ikat sebagai berikut: pertama motif diatur lalu dikat, dan di celup. Selesai di celup, bungkus kembali lalu di ikat kembali, yang di ikat pertama dibuka lalu di celup kembali, setelah di celup kain di buka semua.

Fungsi, Makna dan Kedudukan Kain Tenun Songket Ikat Dusun Semberang dalam Masyarakat

Secara keseluruhan, makna yang ada dalam Kain Tenun itu tergambar dari motifnya. Motif-motif itu menggambarkan makna tertentu dan menunjukkan suatu peristiwa tertentu pula yaitu peristiwa perang yang terjadi pada masa lalu dengan menggunakan senjata perang saja mereka berhasil mengalah musuh, makna ini tergambar dalam motif parang manang.

Motif pucuk rebung menggambarkan makanan khas yang ada di daerah ini yaitu rebung dan filosopinya adalah bahwa rebung itu selalu bertunas dan bertunas lagi. Motif mawar misalnya menggambarkan kesenangan kaum wanita disana pada bunga mawar karena keharuman bunga itu dan warnanya indah. Motif bintang menggambarkan cita-cita yang tinggi.

Keberadaan ikatan dalam kehidupan masyarakat memiliki peran dan nilai yang sangat baik dari segi ekonomi, sosial, dan budaya. Nilai-nilai tersebut dapat dilihat dari perilaku atau kebiasaan masyarakat. Tenun dasi biasanya dibuat oleh wanita.

Kemampuan menenun menentukan derajat wanita. Setiap wanita yang pandai menenun memiliki derajat yang lebih tinggi daripada wanita yang tidak pandai menenun. Ketika dilamar, pihak pria bersedia memberikan mahar sebanyak yang diminta oleh pihak wanita yang pandai menenun.

\section{PRODUKSI KAIN TENUN SONGKET IKAT \\ Proses Produksi}

Menurut bu Nazifah (wan dare) hasil dari wawancara tanggal 18 Januari 2021 menyatakan bahwa, Proses produksi kain tenun ikat tahun 1998-2010 pesanan-pesanan komsumen pada saat itu bertambah banyak dan menyukai kain tenun songket ikat tersebut maupun perempuan ataupun laki- laki.

Sedangkan pemasarannya menyebar luas bermacam-macam tidak ada menambung khusus secara manual, tapi dengan ramainya penjual dan pembeli semakin laris, dan pengrajin di dusun semberang hanya memproduksi diantaranya ada juga komsumen yang mendatangitempat kain tenun songket ikat secara langsung. Tetapi kebanyakan produksi menambah dan pedagang-pedagang pun menyebar luas penjualannya.

Menurut salah satu informan yang bernama $\mathrm{Bu}$ Maniah proses dan harga produksi pembuatan Kain Tenun Polister (bahan kasar) dari sebagai berikut:

\begin{tabular}{c|c|c}
\hline \multicolumn{3}{|c}{ Bahan Dasar Kain } \\
\hline 1 & $\begin{array}{c}\text { Modal Kain Rp. 16.000 } \\
\text { x 2 tukal }\end{array}$ & Rp. 32.000 \\
\hline 2 & Nganek 1 helai & Rp. 6.000 \\
\hline 3 & Ngubung 1 helai & Rp. 50.000 \\
\hline 4 & Pakan yamalon 1 buah & Rp. 16.000 \\
\hline 5 & $\begin{array}{c}\text { Benang kelengkang 1 } \\
\text { buah }\end{array}$ & Rp. 20.000 \\
\hline 6 & $\begin{array}{c}\text { Benang emas kristal 5 } \\
\text { unting }\end{array}$ & Rp. 100.000 \\
\hline 7 & Upah 1 helai & Rp. 280.000 \\
\hline & Jumlah & Rp. 504.000 \\
\hline
\end{tabular}

\begin{tabular}{c|c|c}
\hline \multicolumn{3}{|c}{ Modal 1 Helai Sabuk } \\
\hline 1 & $\begin{array}{c}\text { Modal benang Rp. } \\
16.000 \times \text { x tukal }\end{array}$ & Rp. 32.000 \\
\hline 2 & Nganek 1 helai & Rp. 5.000 \\
\hline 3 & Ngubung 1 helai & Rp. 50.000 \\
\hline 4 & Pakan yamalon 1 buah & Rp. 16.000 \\
\hline 5 & $\begin{array}{c}\text { Benang kelengkang 1 } \\
\text { buah }\end{array}$ & Rp. 20.000 \\
\hline
\end{tabular}




\begin{tabular}{c|c|c}
\hline 6 & $\begin{array}{c}\text { Benang emas kristal 3 } \\
\text { unting }\end{array}$ & Rp. 60.000 \\
\hline 7 & Upah 1 helai & Rp. 200.000 \\
\hline \multicolumn{2}{c}{ Jumlah } & Rp. 383.000 \\
\hline
\end{tabular}

\begin{tabular}{|c|c|c|}
\hline \multicolumn{3}{|c|}{ Modal 1 Helai Selendang } \\
\hline 1 & $\begin{array}{l}\text { Benang dasar } 1 \text { helai } \\
\text { selendang }\end{array}$ & Rp. 16.000 \\
\hline 2 & Nganek 1 helai & Rp. 5.000 \\
\hline 3 & Ngubung 1 helai & Rp. 50.000 \\
\hline 4 & Pakan yamalon 1 buah & Rp. 10.000 \\
\hline 5 & $\begin{array}{c}\text { Benang kelengkang } 1 \\
\text { buah }\end{array}$ & Rp. 20.000 \\
\hline 6 & $\begin{array}{c}\text { Benang emas kristal } 2 \\
\text { unting }\end{array}$ & Rp. 40.000 \\
\hline 7 & Upah 1 helai & Rp. 170.000 \\
\hline & Jumlah & Rp. 311.000 \\
\hline
\end{tabular}

bahwa,

Menurut $\mathrm{Bu}$ Fitrianti menyatakan

Proses pembelajaran generasi muda di daerah semberang jamaan dulu orang hanya melihat orang menenun saja, sekarang orang generasi muda tidak semua mau belajar karena adanya kendala, seperti ada yang sekolah, ada yang kuliah, jadi waktu merek tidak terlalu fokus untuk menenun. Sedangkan orang yang sudah menikah dan menjadi ibu rumah tangga terpaksa harus bekerja sebagai penenun.

Pekerjaan yang diberikan oleh pengelola tenun itu dengan targek jumlah hasil produksi atau waktu penyelesaiannya pekerjaaan. Misalna seorang penenun harus menyelesaikan 3 lembar kain dalam satu bulan, tetapi karena kelalaian si penenun itu dalam melakukan tugasnya, sehingga waktunya melebihi dari jadwal yang diberikan pengelola tenun tersebut. Sekalipun mereka terlambat dalam menyelesaikan pekerjaannya, tetapi karena tidak ada sanski yang diberikan oleh pengusaha tersebut sehingga kejadian seperti ini berulang kali terjai. Sebenarnya dalam sebulan itu dapat menghasilkan 2-3 benang helai kain. Hal ini tergantung kemauan dari penenun itu sendiri, seandainya mereka giat dalam bekerja maka upahnya yang didapatkan pun lebih banyak. Modal

Menurut Bu Nazifah (Wan Dare) menyatakan bahwa,

Modal Awal Dalam Kelompok Usaha Bersama Sedikit Mengumpulkan Dan Dibantu Juga Sama Diprindak Tetapi Tidak Banyak Yang Diberikan Hanya Bahan Baku (Benang Emas), Sedangkan Alat Tenun Masing-Masing Penenun Bertahap Dari Nol Cuma Hanya Bisa Membentuk Kelompok. Sedangkan Modal Sendiri Dari Bahan Baku (Benang Emas), Dikerjakan Sendiri Modalnya Kisaran Jutaan, Dari Alatnya Sendiri Sudah Termasuk Mahal Bisa Dikelola Sekitar Lima Juta.

Selain itu ada juga modal binaan dari Garuda Jakarta, tetapi sebenarnya orang sudah pandai menenun, sudah pandai juga mencelup (memberi warna), ada modal tetapi tidak banyak dan bisa dikelola sendri. Dari Garuda sendiri memberikan modal, tetapi Garuda hanya mengambil untuk pelatihan saja. Ketua Garuda sendiri orang CTI yang dipercayai oleh pemerintah untuk meluaskan Kain Tenun Sambas, Kain Tenun dari Sumatera, Kain Tenun dari Sulawesi dan Kain Tenun adat lainnya. Ada satu binaan yang lainnya yaitu binaan Dompet Umat ialah yang benar-benar membantu tetapi tidak banyak, Dompet Umat membantu satu orang mendapatkan satu bantuan, dompet umat membantu dari alat sampai bahan baku, kadang-kadang sampai pasaran tetapi tidak semuanya memasarkannya.

$$
\text { tergantung pengelola }
$$

Program pemberdayaan ini bertujuan untuk meningkatkan kesejahteraan penenun sekaligus melestarikan kain tenun ikat Songket Sambas yang berasal dari Kabupaten Sambas. Bentuk Program Pemberdayaan Kain Tenun Sambas oleh Dompet Ummat adalah pemberian bantuan modal dan pelatihan kepada penerima program mustahik yang merupakan penenun kain Sambas. Bantuan modal yang diberikan berupa alat tenun dan benang tenun serta uang tunai sebagai tambahan modal. 


\section{Tenaga kerja}

Tenaga kerja dan modal tidak diperlukan untuk tingkat produksi biasa perusahaan. Tenaga kerja merupakan salah satu faktor produksi yang memegang peranan penting bagi suatu perusahaan. Oleh karena itu, perusahaan perlu mempertahankan peran tenaga kerja dan berupaya untuk meningkatkan produktivitas tenaga kerjayang tentunya disesuaikan dengan keadaan perusahaan agar produktivitas kerja karyawan tetap terjaga dan peluang untuk selalu meningkatkan produktivitas dapat dicapai dengan sebaik-baiknya.

Masa banyaknya pesanan itu disebabkan karena pembeli itu datang kepada para pengusaha baik yang datangnya dari Kabupaten Sambas itu sendiri, luar Kabupaten dan bahkan dari Negeri tetangga, baik Malaysia maupun dari Brunei Darussalam. Banyak permintaan Kain Tenun Songket baik yang dipergunakan sebagai Kain maupun Sabuk menyebabkan para pengrajin semakin giat dalam melakukan usahanya. Sekalipun kendala mereka dalam permodalan tetapi dengan usaha dan kemauan yang keras sehingga mereka mendapatkan bantuan dari pemerintah dengan pemberian kredit. bahwa,

Menurut $\mathrm{Bu}$ Saninah menyatakan

"Satu orang menenun kain tenun songket untuk 1 set waktunya sampai 3 bulan. Sedangkan 3 orang penenun dibagi pekerjaan nya masing-masing yang sudah ada tugasnya. Untuk kain 1 orang waktu pekerjaannya sampai 3 minggu/helai, selendang besar dan kecil masing-masing 1 orang waktu pekerjaannya sampai 1 minggu, dan untuk sabuk 1 orang waktu pekerjaannya sampai 2 minggu/helai.

Pengaruh positif tenaga kerja terhadap kualitas produksi Kain Tenun Ikat disesuaikan dengan teori yang ada bahwa tenaga kerja merupakan faktor yang sangat penting dan diperhitungkan dalam proses produksi. Jumlah tenaga kerja harus diperhitungkan dalam proses produksi. Jumlah tenaga kerja harus mencukupi, tidak hanya dari segi ketersediaan, tetapi juga dari segi kualitas dan jenis tenaga kerja itu sendiri.

\section{SIMPULAN DAN SARAN Simpulan}

Sebuah kerajinan Kain Tenun Songket Ikat salah satu tradisi budaya yang masih ada pada zaman era modern, yang memilki beberapa daerah tertentu. Meskipun terdapat perbedaan, biasanya terletak pada jenis dan susunan motifnya. Tradisi budaya tersebut adalah tradisi budaya menenun Tenun Songket Sambas.

Motif dalam Tenun Songket Ikat ini terdapat beberapa kelompok seperti kelompok tumbuh-tumbuhan (flora), kelompok hewan (fauna), kelompok lingkungan alam, kelompok ilmu ukur, huruf dan sebagainya. Kelompok motif yang diangkat berdasarkan tumbuh-tumbuhan (flora), seperti bunga matahari, bunga tanjung, bunga melati, bunga sebangar, bunga tapak dara, bunga penyu, bunga malek, bugga anggur, bunga jeruk, aluk paku, sapar peranggi, dan daun periya.

Proses pembuatan Kain Tenun Ikat Songket menggunakan ATBM (Alat Tenun Bukan Mesin) yaitu alat yang terbuat dari kayu, sebuah alat tenun yang terdiri dari beberapa bagian, yang masing-masing alat ini saling mendukung ketika dikendalikan.

\section{Saran}

Sebaiknya untuk remaja-remaja yang ada di Dusun Semberang senantiasa untuk ikut serta mengembangkan dan melestarikan Kain Tenun Songket Ikat dengan perlahan- lahan belajar membuat Kain Tenun Songket Ikat.

\section{DAFTAR RUJUKAN}

Fahmi (2018). Boklet Dinas Pendidikan dan Kebudayaan. Kabupaten Sambas.

Damardjati dan Asnaini. (2011). Industri Kerajinan Kain Tenun Sambas Strategi Pengembangan Warisan Budaya. Kepel Press, Anggota IKAPI. Yogyakarta.

Kartiwa, S. (1993). Tenun Ikat Indonesia Ikat. Jakarta. Djambatan

Kuntowijoyo. (2003). Metodologi Sejarah. PT. Tiara Wacana. Yogyakarta. 
Kunjowijoyo. (2008). Penjelasan Sejarah. Tiara Wacana. Yogyakarta.

Sjamsudin Helius. (2019). Metodologi Sejarah. Cetakan III. Yogyakarta: Ombak.

Sari N.M. (2014) Tenun Ikat ATBM HOME INDUSTRY Kurniawan Bandar Kidul Kediri Jawa Timur. Fakultas Seni dan Bahasa Universitas Negeri Yogyakarta.
Therik,J. A. (1989 ). Tenun Ikat dari Timur Keindahan Anggun Warisan Leluhur/Ikat.Jakaerta:Pustaka Sinar harapan. 
